\title{
Zinc Redistribution in a Soil Developed from Limestone During Pedogenesis*1
}

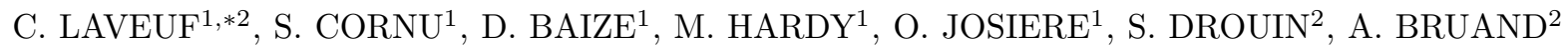 \\ and F. JUILLOT ${ }^{3}$ \\ ${ }^{1}$ INRA, UR0272 Science du Sol, Centre de recherche d'Orléans, 45075 Orléans cedex 2 (France) \\ ${ }^{2}$ ISTO, UMR 6113, CNRS, Université d'Orléans, 45071 Orléans cedex 2 (France) \\ ${ }^{3}$ IMPMC, UMR CNRS 7590, Université Paris 6 et 7, IPGC, 75252 Paris cedex 05 (France)
}

(Received November 20, 2008; revised March 23, 2009)

\begin{abstract}
The long-term redistribution of $\mathrm{Zn}$ in a naturally Zn-enriched soil during pedogenesis was quantified based on mass balance calculations. According to their fate, parent limestones comprised three Zn pools: bound to calcite and pyritesphalerite grains, bound to phyllosilicates and bound to goethite in the inherited phosphate nodules. Four pedological processes, i.e., carbonate dissolution, two stages of redox processes and eluviation, redistributed Zn during pedogenesis. The carbonate dissolution of limestones released $\mathrm{Zn}$ bound to calcite into soil solution. Due to residual enrichment, Zn concentrations in the soil are higher than those in parent limestones. Birnessite, ferrihydrite and goethite dispersed in soil horizon trapped high quantities of $\mathrm{Zn}$ during their formation. Afterwards, primary redox conditions induced the release of $\mathrm{Zn}$ and Fe into soil solution, and the subsequent individualization of Fe and Mn into Zn-rich concretions. Both processes and subsequent aging of the concretions formed induced significant exportation of Zn through the bottom water table. Secondary redox conditions promoted the weathering of Fe and Mn oxides in cements and concretions. This process caused other losses of $\mathrm{Zn}$ through lateral exportation in an upper water table. Concomitantly, eluviation occurred at the top of the solum. The lateral exportation of eluviated minerals through the upper water table limited illuviation. Eluviation was also responsible for $\mathrm{Zn}$ loss, but this $\mathrm{Zn}$ bound to phyllosilicates was not bioavailable.
\end{abstract}

Key Words: carbonate dissolution, eluviation, long-term, redox, speciation

Citation: Laveuf, C., Cornu, S., Baize, D., Hardy, M., Josiere, O., Drouin, S., Bruand A. and Juillot, F. 2009. Zinc redistribution in a soil developed from limestone during pedogenesis. Pedosphere. 19(3): 292-304.

Although $\mathrm{Zn}$ is an essential nutrient for living organisms, this element exhibits a well-established toxic nature for fauna and flora at high concentrations in soils. Studies dealing with the geochemical behaviour of Zn focused particularly on polluted soils, because numerous human activities lead to accumulations of Zn in soils, which can represent an environmental hazard (Salomons et al., 1995). However, some soils developed on natural geochemical anomalies display concentrations of $\mathrm{Zn}$ as high as those of polluted soils (Kabata-Pendias and Pendias, 2001), but to our knowledge, no Zn toxicity for plants was recorded on these large cropping areas (Nicolini, 1990). The fate of $\mathrm{Zn}$ in soils depends not only on its total concentration, since its potential mobility and bioavailability are governed by its speciation and location in relationship to roots, and by its rate of release into the soil solution.

As a general rule, geogenic trace elements including $\mathrm{Zn}$ are believed to be less mobile than those of anthropogenic origin, but few empirical datasets published support this hypothesis. In this study we tested the hypothesis that the lower mobility of geogenic Zn in soils relative to anthropogenic Zn was due to differences in speciation. The present work aimed at quantifying the long-term redistribution of $\mathrm{Zn}$ due to different pedological processes during the pedogenesis of a soil developed on natural geochemical anomalies. The approach consisted in determining the speciation sensu largo of $\mathrm{Zn}$, i.e., its repartition

\footnotetext{
*1 Project supported by the "GDR TRANSMET" Program of the Centre National de la Recherche Scientifique (CNRS), France.

${ }^{* 2}$ Corresponding author. E-mail: laveuf@orleans.inra.fr.
} 
Zinc Fate Through Pedogenesis

within the different solid components, both in the parent material and in the solum. Information on the speciation of Zn was cross-linked with mass balance calculations according to the Brimhall approach in order to estimate the fluxes of Zn due to each pedological process identified (Brimhall et al., 1991).

\section{MATERIALS AND METHODS}

\section{Studied site and samples}

The studied site, located $2.5 \mathrm{~km}$ southward of Pouilly-en-Auxois (Burgundy, France), consists in a thick and old forested solum, which developed from limestones dated from the Sinemurian and Lotharingian (upper Sinemurian). The Sinemurian-aged limestone is 5- to 10-m thick and consists of hard and compact crystalline grey-blue limestone layers irregularly intercalated with thin soft marled beds. The overlying Lotharingian-aged limestone is 1- to 3-m thick and consists of a grey-blue matrix with brown-rust coloured inclusions and of a bed of pluricentimetric phosphate nodules corresponding to marine fossils at its bottom. Mineralization events due to hydrothermal fluids rising along fault lines during the Lias epoch (Baize and Chrétien, 1994) are responsible for their high contents of Zn.

The studied solum is composed of the succession of horizons described in Table I. The limit with the unweathered and impermeable Sinemurian-aged limestone undulates between 170- and 180-cm depth. The abundant phosphate nodules in the BP-horizon were inherited from the bed of phosphate nodules at the bottom of the Lotharingian-aged limestone. Consequently, the overlying horizons derived from the autochthonous weathering of the Lotharingian-aged limestone, whereas the underlying ones derived from the autochthonous weathering of the Sinemurian-aged limestone. Indeed, Baize and Chrétien (1994) assessed the autochthony of these soils by petrography coupled with geochemical and mineralogical analyses, avoiding significant contribution of loess deposits in the studied area. The soil horizons identified were sampled on the whole width of a pit, once when homogenous or all $10 \mathrm{~cm}$ when an evolution with depth was evidenced.

\section{TABLE I}

Characteristics of the soil horizons (from top to bottom) in the studied solum

\begin{tabular}{|c|c|c|}
\hline Horizon & Soil depth & Characteristic \\
\hline & $\mathrm{cm}$ & \\
\hline A & $0-(10-15)$ & Yellowish brown (10YR5/4), with few small black Fe-Mn concretions \\
\hline $\mathrm{E}$ & $(10-15)-45$ & $\begin{array}{l}\text { Yellowish brown }(10 \mathrm{YR} 5 / 6 \text { to } 4 / 4) \text {, depleted in clay particle-size fractions, with few small } \\
\text { black Fe-Mn concretions at the top (E1), more numerous ones at the bottom (E2) }\end{array}$ \\
\hline $\mathrm{Bd}$ & $45-(75-80)$ & $\begin{array}{l}\text { Ochre (10YR4/4), irregularly bleached and degraded, with small black numerous Fe-Mn con- } \\
\text { cretions and few small phosphate nodules }\end{array}$ \\
\hline $\mathrm{Bc}$ & $(75-80)-95$ & $\begin{array}{l}\text { Compact, with numerous Fe-Mn concretions and abundant big white soft phosphate nodules } \\
(1 \text { to } 2 \mathrm{~cm})\end{array}$ \\
\hline $\mathrm{BP}$ & $95-145$ & $\begin{array}{l}\text { Ochre (10YR } 4 / 4 \text { to } 5 / 4 \text { ), with few phosphate nodules and abundant black Fe-Mn concretions } \\
\text { that are ovoid-shaped, hard, from various sizes (less than } 0.5 \text { to more than } 5 \mathrm{~mm} \text { ) and disco- } \\
\text { rdant with the matrix of the horizon }\end{array}$ \\
\hline $\mathrm{C}$ & $145-(170-180)$ & Ochre (10YR5/6), clay-rich, developed in a water table, with rare Fe-Mn concretions \\
\hline
\end{tabular}

The Lotharingian-aged limestone (abbreviated L, excluding the bed of phosphate nodules at its bottom) was sampled in a road trench, 800 meters southward of the studied pit where it is completely weathered. One sample of the Sinemurian-aged limestone (abbreviated S) was taken at the bottom of the pit (S1) and three additional ones from different strata on the same road trench (S2, S3 and S4).

Analyses on soil samples

Bulk density of each soil horizon was determined in triplicate by the cylinder method after drying at $105{ }^{\circ} \mathrm{C}$. Pedological analyses were performed at the Laboratoire d'Analyse des Sols (LAS, Arras, France): $\mathrm{pH}$ was determined according to the standard protocol NF ISO 10390; $\mathrm{CaCO}_{3}$ according to 
NF ISO 10693 (calcimetry); organic matter (OM) obtained by multiplying by 1.73 the organic carbon measured according to NF ISO 10694. Total major elements were analyzed at the Service d'Analyse des Roches et des Minéraux (SARM, Vandoeuvre-lès-Nancy, France) by ICP-AES and Zn by ICP-MS after $\mathrm{LiBO}_{2}$ fusion. Results being in the range of those reported by Baize and Chrétien (1994) (Table II), the studied solum is thus representative of those encountered in the studied area.

TABLE II

Main pedological characteristics, total Fe, Mn, P and Zn concentrations and volumetric strain $(\varepsilon)$ of the different soil horizons

\begin{tabular}{|c|c|c|c|c|c|c|c|c|c|c|}
\hline Horizon & Depth & $\mathrm{pH}_{\text {water }}$ & Base saturation & $\mathrm{CaCO}_{3}$ & Organic matter & $\mathrm{Fe}$ & Mn & $\mathrm{P}$ & $\mathrm{Zn}$ & $\varepsilon$ \\
\hline & $\mathrm{cm}$ & & $\%$ & \multicolumn{5}{|c|}{$\mathrm{g} \mathrm{kg}^{-1}$} & $\mathrm{mg} \mathrm{kg}^{-1}$ & $\%$ \\
\hline $\mathrm{A}$ & $0-10$ & 5.7 & 36 & 1.2 & 53 & $40^{\S}$ & $2.3^{\diamond}$ & $1.7^{\#}$ & $129^{+}$ & -85.1 \\
\hline E1 & $20-30$ & 5.8 & 42 & 0 & 25 & $47^{\S}$ & $2.3^{\diamond}$ & $1.3^{\#}$ & $146^{+}$ & -86.0 \\
\hline $\mathrm{E} 2$ & $35-45$ & 5.5 & 42 & 0 & 11 & $60^{\S}$ & $3.5^{\diamond}$ & $1.7^{\#}$ & $189^{+}$ & -83.2 \\
\hline $\mathrm{Bd} 1$ & $50-60$ & 5.8 & 67 & 0 & 9 & $78^{\S}$ & $8.3^{\S}$ & $4.2^{\#}$ & $315^{+}$ & -79.9 \\
\hline $\mathrm{Bd} 2$ & $60-70$ & - & - & - & - & $89^{\S}$ & $9.2^{\S}$ & $3.8^{\#}$ & $337^{+}$ & -80.0 \\
\hline $\mathrm{BP}$ & $80-90$ & 6.3 & 77 & 2.7 & 6 & $94^{\S}$ & $14^{\S}$ & $61^{+}$ & $772^{+}$ & - \\
\hline $\mathrm{Bc} 1$ & $105-115$ & - & - & - & - & $86^{\S}$ & $16^{\S}$ & $15^{+}$ & $508^{+}$ & -82.9 \\
\hline $\mathrm{Bc} 2$ & $115-125$ & 7.0 & 86 & 1.2 & 8 & $83^{\S}$ & $12^{\S}$ & $8.0^{+}$ & $475^{+}$ & -80.7 \\
\hline Bc3 & $125-135$ & - & - & - & - & $86^{\S}$ & $12^{\S}$ & $9.0^{+}$ & $481^{+}$ & -80.3 \\
\hline $\mathrm{Bc} 4$ & $135-145$ & - & - & - & - & $90^{\S}$ & $15^{\S}$ & $9.0^{+}$ & $515^{+}$ & -80.2 \\
\hline $\mathrm{C}$ & $145-170$ & 7.9 & 100 & 22 & 11 & $90^{\S}$ & $8.0^{\S}$ & $4.4^{+}$ & $919^{+}$ & -82.4 \\
\hline
\end{tabular}

$\S,+, \#, \diamond$ Analytical error of $2 \%, 5 \%, 10 \%$, and $15 \%$, respectively.

The A-, E1-, Bd1-, BP-, Bc2- and C-soil samples were wet-sieved at 500, 200 and $50 \mu \mathrm{m}$ in deionized water, without preliminary treatments. The remaining fractions $(<50 \mu \mathrm{m})$ were further fractionated by sedimentation in deionized water according to Stokes law. The particle-size fractions obtained were: $0-2,2-20,20-50,50-200,200-500$ and $>500 \mu \mathrm{m}$. Organic fragments were removed from the fractions $>500 \mu \mathrm{m}$ by water flotation before total chemical analysis of the remaining mineral fractions. For the BP- and all Bc-horizons, all phosphate nodules and Fe-Mn concretions larger than $1 \mathrm{~mm}$ were manually sorted. All fractions (particle-size fractions, soil-phosphate nodules and Fe-Mn concretions) were analyzed for $\mathrm{Fe}, \mathrm{Mn}, \mathrm{Al}, \mathrm{Si}$ and $\mathrm{Zn}$ at the SARM as described above.

X-ray diffraction (XRD) analyses on powder were performed on bulk samples, 2-20 $\mu \mathrm{m}$ fractions, soil-phosphate nodules and Fe-Mn concretions, with $2 \theta$ ranging from $0^{\circ}$ to $75^{\circ}$ and a counting time of $1 \mathrm{~s} / 0.02^{\circ}$. XRD analyses on natural, glycoled and heated oriented slides were performed on 0-2 $\mu \mathrm{m}$ particle-size fractions, with $2 \theta$ ranging from $0^{\circ}$ to $47^{\circ}$ and a counting time of $20 \mathrm{~s} / 0.02^{\circ}$. All diffraction data were obtained using $\mathrm{CuK} \alpha$ radiation $(45 \mathrm{kV}, 30 \mathrm{~mA})$.

Since the solum is rich in Fe and Mn (Table II), the chosen 8-step procedure of sequential extractions, adapted from Hall et al. (1996) and Cornu et al. (2006), focused particularly on the extraction of Fe and $\mathrm{Mn}$ oxides. Extractions were performed in triplicate on $1 \mathrm{~g}$ of the bulk sample ground to $50 \mu \mathrm{m}$ for the A-, E1-, Bd1- and C-horizons and on $1 \mathrm{~g}$ of the fraction $<50 \mu \mathrm{m}$ for the BP- and Bc2-horizons, under permanent shaking and at ambient temperature, if not specified.

Step 1 was a single extraction with $10 \mathrm{~mL}$ of a solution of $\mathrm{NaNO}_{3} 0.1 \mathrm{~mol} \mathrm{~L}^{-1}$ (analytical reagent, AR, Chem-Lab) for $120 \mathrm{~min}$; step 2 a single extraction with $20 \mathrm{~mL}$ of a solution of $\mathrm{CH}_{3} \mathrm{COONa} 1$ mol L ${ }^{-1}$ (ultra pure, UP, Chem-Lab) adjusted to $\mathrm{pH} 5.5$ with $\mathrm{CH}_{3} \mathrm{COOH} 99 \%-100 \%$ (UP, Chem-Lab) for $360 \mathrm{~min}$; step 3 twofold extraction with $20 \mathrm{~mL}$ of a solution of $\mathrm{NH}_{2} \mathrm{OH} \cdot \mathrm{HCl} 0.1 \mathrm{~mol} \mathrm{~L}{ }^{-1}$ (AR, Chem-Lab)/HCl $0.1 \mathrm{~mol} \mathrm{~L}^{-1}$ (UP, Prolabo Normatom) at pH 2.0 for $30 \mathrm{~min}$; step 4 a single extraction with $10 \mathrm{~mL}$ of a solution of $\mathrm{Na}_{4} \mathrm{P}_{2} \mathrm{O}_{7} 0.1 \mathrm{~mol} \mathrm{~L}-1$ (AR, Prolabo Merck) at pH 10 for $90 \mathrm{~min}$; step 5 twofold extraction with $20 \mathrm{~mL}$ of a solution of $\mathrm{NH}_{2} \mathrm{OH} \cdot \mathrm{HCl} 0.25 \mathrm{~mol} \mathrm{~L}{ }^{-1}$ (AR, Chem-Lab)/HCl 0.25 mol L ${ }^{-1}$ (UP, Prolabo Normatom) at $\mathrm{pH} 1.5$ and $60{ }^{\circ} \mathrm{C}$ for $120 \mathrm{~min}$; step 6 twofold extraction with $30 \mathrm{~mL}$ of a solution of $\mathrm{NH}_{2} \mathrm{OH} \cdot \mathrm{HCl} 1 \mathrm{~mol} \mathrm{~L}{ }^{-1}$ (AR, Chem-Lab) $/ \mathrm{CH}_{3} \mathrm{COOH} 99 \%-100 \%$ at $25 \%$ (UP, Chem-Lab) at pH 1.0 and $90{ }^{\circ} \mathrm{C}$ for $180 \mathrm{~min}$, then $90 \mathrm{~min}$; step 7 a single extraction with $750 \mathrm{mg}$ of 
$\mathrm{KClO}_{3}$ (AR, Chem-Lab) and $15 \mathrm{~mL}$ of a solution of $\mathrm{HCl} 12 \mathrm{~mol} \mathrm{~L}^{-1}$ (AR, ChemLab) for $30 \mathrm{~min}$, then another extraction with $10 \mathrm{~mL}$ of a solution of $\mathrm{HNO}_{3} 4 \mathrm{~mol} \mathrm{~L}{ }^{-1}$ (UP, Chem-Lab) at $90{ }^{\circ} \mathrm{C}$ for $20 \mathrm{~min}$.

The residual fraction of step 7 was analyzed for Fe, Mn and Zn at the SARM. After each step, a rinse with $20 \mathrm{~mL}$ of $\mathrm{MilliQ}{ }^{\circledR}$ water was performed for $1 \mathrm{~h}$. The extraction and rinse solutions were centrifuged at $10800 \times g$ and filtered through a $0.2-\mu \mathrm{m}$ pore-size membrane in cellulose acetate. Blanks were realized following the same procedures. Filtrates were acidified to $1 \%$ with $\mathrm{HNO}_{3} 65 \%$ (UP, Chem$\mathrm{Lab}$ ) if necessary and individually stored at $4{ }^{\circ} \mathrm{C}$ before analyses for $\mathrm{Fe}, \mathrm{Mn}$ and $\mathrm{Zn}$ by spectroscopic flame atomic absorption. All values of $\mathrm{Fe}, \mathrm{Mn}$ and $\mathrm{Zn}$ for extraction results discussed hereafter were corrected from those measured in the blanks that were near or below the limits of detection. Differential XRD was performed following Schulze (1981), in order to determine the minerals dissolved during sequential extractions: bulk samples and residues from extractions were analyzed on powder with $2 \theta$ ranging from $36^{\circ}$ to $48^{\circ}$ and a counting time of $50 \mathrm{~s} / 0.02^{\circ}$.

A decimetric soil monolith was sampled in the BP-horizon with a Kubiena box. Two thin sections $\left(45 \times 60 \mathrm{~mm}^{2}, 25 \mu \mathrm{m}\right.$ thick) containing typical phosphate nodules were realized. They were observed with a scanning electron microscope (SEM, Cambridge Stereoscan 90B), and analyzed for Fe and Zn with a microprobe (Cameca SX50; with a beam voltage of $15 \mathrm{keV}$, a beam current of $12 \mathrm{nA}$ and a counting time of $10 \mathrm{~s}$ for Fe and $30 \mathrm{~s}$ for Zn) and by proton induced X-ray emission (PIXE; vertical Van de Graaff accelerator HV-KN-3000; with a proton beam energy of $3 \mathrm{MeV}$ and a beam current ranging from 1 to $200 \mu \mathrm{A}$ on a $30 \times 60 \mu \mathrm{m}^{2}$ area).

\section{Analyses on limestone samples}

Limestone-phosphate nodules (S2P) were separated from carbonated matrix (S2M) in sample S2. Unweathered parts of all limestone samples were selected and analyzed for $\mathrm{Fe}, \mathrm{Mn}, \mathrm{Al}, \mathrm{Si}, \mathrm{Ca}, \mathrm{P}$ and $\mathrm{Zn}$ at the SARM and for $\mathrm{CaCO}_{3}$ at the LAS. Bulk density of each limestone sample was determined in triplicate on three different pieces (sizes of about $5 \times 5 \times 5 \mathrm{~cm}^{3}$ ) by volume displacement in kerosene after drying at $40{ }^{\circ} \mathrm{C}$. Unweathered limestone samples (L, S1, S2M) and limestone-phosphate nodules (S2P) were roughly ground. About $10 \mathrm{~g}$ of each sample were put in closed batches with $30 \mathrm{~mL}$ of MilliQ ${ }^{\circledR}$ water and placed onto a magnetic agitator at room temperature. $\mathrm{pH}$ was monitored along the experiment. A solution of $\mathrm{HCl} 1 \mathrm{~mol} \mathrm{~L}^{-1}$ was introduced, regulating the flow in order to maintain $\mathrm{pH}>5$ and to avoid the alteration of Fe oxides and of phyllosilicates. The limestone residues from carbonate dissolution were analyzed for $\mathrm{Fe}, \mathrm{Mn}, \mathrm{Al}, \mathrm{Si}, \mathrm{Ca}, \mathrm{P}$ and $\mathrm{Zn}$ at the SARM and for $\mathrm{CaCO}_{3}$ at the LAS. X-ray diffraction (XRD) analyses on powder were performed on the limestone residues, with $2 \theta$ ranging from $0^{\circ}$ to $75^{\circ}$ and a counting time of $8 \mathrm{~s} / 0.02^{\circ}$. Surface-indurated sections $(25 \mathrm{~mm}$ in diameter, $5 \mathrm{~mm}$ thick) of samples S2M, S3, S4 and L were prepared and analyzed with a microprobe for $\mathrm{Ca}, \mathrm{P}, \mathrm{F}, \mathrm{Si}, \mathrm{Al}, \mathrm{Fe}, \mathrm{Mn}$, and of $30 \mathrm{~s}$ for $\mathrm{S}$ and $\mathrm{Zn}$ as described above.

\section{Mass balance calculations}

Current stocks of $\mathrm{Zn}, \mathrm{Al}, \mathrm{Si}, \mathrm{Fe}$ and $\mathrm{Mn}$ were calculated for each soil horizon. Element fluxes, $m_{j \text {,hor }}$, were computed for each soil horizon with the procedure and detailed equations of Brimhall et al. (1991) modified by Egli and Fitze (2000), on the basis of the volumetric strain $\varepsilon$, i.e., the soil volume change through time (Table II), and of the mass-transport function $\tau_{j \text {,hor }}$, i.e., the mass fraction of element $j$ gained or lost from the weathered product compared to its initial mass in the parent material. Zirconium, relatively immobile in soils (Brimhall et al., 1991), was used as immobile element.

The choice of the parent material used as a reference is of prime importance in these calculations. The studied solum formed from two different limestones. The A-, E1-, E2-, Bd1- and Bd2-horizons were issued from the weathering of the Lotharingian-aged strata. Their reference was thus the L limestone. The four Bc-horizons were issued from the weathering of Sinemurian-aged strata, since located just beneath the BP-horizon, and contain small phosphate nodules. The S2M limestone was sampled just beneath the bed of phosphate nodules at the bottom of the L limestone and contains also small phosphate 
nodules. The S2M limestone was thus the reference for the Bc-horizons. The C-horizon overlies the S1 limestone. This limestone was thus the reference for the C-horizon. Initial stocks of $\mathrm{Zn}, \mathrm{Al}, \mathrm{Si}, \mathrm{Fe}$ and $\mathrm{Mn}$ in these parent materials were finally calculated.

Mass balance calculations were not performed on the BP-horizon, because the occurrence of pluricentimetric phosphate nodules seriously impeded precise volumetric strain calculations. Errors on calculations were estimated by the classical mathematical methodology of the total differential equations, using the analytical errors given by the SARM for chemical concentrations and the experimental standard deviations for bulk densities.

\section{RESULTS AND DISCUSSION}

\section{Zinc location in the parent materials}

Limestones L, S1 and S2M mainly consisted of calcite and displayed low concentrations of Zn (Table III). The stock percentages released into solution during dissolution from the Sinemurian- and Lotharingian-aged limestones were about $15 \%$ and $40 \%$ for $\mathrm{Zn}, 10 \%$ and $15 \%$ for Fe, and $85 \%$ and $95 \%$ for $\mathrm{Mn}$, respectively, indicating that these elements were bound to calcite (Table III).

\section{TABLE III}

Chemical composition of the bulk samples of the Lotharingian and Sinemurian-aged limestones, their residues from carbonate dissolution and their estimated calcite contents derived from the previous data

\begin{tabular}{|c|c|c|c|c|c|c|c|c|}
\hline Sample & Abbreviation $^{\text {a) }}$ & Fraction considered & $\mathrm{CaCO}_{3}$ & $\mathrm{Ca}$ & $\mathrm{Fe}$ & $\mathrm{Mn}$ & $\mathrm{P}$ & $\mathrm{Zn}$ \\
\hline & & & & & $\mathrm{g} \mathrm{kg}^{-1}$ & & & $\mathrm{mg} \mathrm{kg}^{-1}$ \\
\hline \multirow[t]{3}{*}{ Lotharingian-aged limestone } & $\mathrm{L}$ & Bulk & $872^{b)}$ & $339^{\S}$ & $23.7^{\S}$ & $1.9^{\diamond}$ & $4.0^{\#}$ & $38^{\#}$ \\
\hline & & Residue & - & $14.4^{+}$ & $164^{\S}$ & $0.9^{\diamond}$ & $14.4^{+}$ & $169^{+}$ \\
\hline & & Calcite $^{\mathrm{c})}$ & - & 387 & 3.1 & 2.1 & 2.4 & 19 \\
\hline \multirow[t]{9}{*}{ Sinemurian-aged limestone } & $\mathrm{S} 1$ & Bulk & $880^{\mathrm{d})}$ & $350^{\S}$ & $10.3^{\S}$ & $2.3^{\diamond}$ & $5.6^{+}$ & $11^{\#}$ \\
\hline & & Residue & - & $292^{*}$ & $81^{\S}$ & $0.44^{\diamond}$ & $45^{+}$ & $62^{+}$ \\
\hline & & Calcite $^{\mathrm{c})}$ & - & 387 & 0.9 & 2.6 & 0.5 & 4.4 \\
\hline & $\mathrm{S} 2 \mathrm{M}$ & Bulk & $683^{\mathrm{b})}$ & $322^{\S}$ & $9.5^{\S}$ & $1.9^{\diamond}$ & $1.8^{\#}$ & $77^{+}$ \\
\hline & & Residue & - & $302^{\S}$ & $22.9^{\S}$ & $1.9^{\diamond}$ & $3.3^{\#}$ & $189^{+}$ \\
\hline & & Calcite $^{\mathrm{c}}$ & - & 377 & 3.3 & 1.9 & 1.1 & 25.0 \\
\hline & $\mathrm{S} 2 \mathrm{P}$ & Bulk & $278^{\mathrm{b})}$ & $352^{\S}$ & $53^{\S}$ & $1.3^{\diamond}$ & $92^{+}$ & $1179^{+}$ \\
\hline & & Residue & - & $91.8^{\S}$ & $62^{\S}$ & $1.2^{\diamond}$ & $123^{+}$ & $1327^{+}$ \\
\hline & & Calcite $^{\mathrm{c})}$ & - & 375 & 31.2 & 1.5 & 11.1 & 795 \\
\hline
\end{tabular}

$\S,+, \#, \diamond$ Analytical error of $2 \%, 5 \%, 10 \%$, and $15 \%$, respectively.

a) $\mathrm{S} 2 \mathrm{M}$ stands for carbonated matrix and $\mathrm{S} 2 \mathrm{P}$ for phosphate nodules in sample $\mathrm{S} 2$; b) Determined by the loss of mass after experimental carbonate dissolution in batch experiment; ${ }^{c}$ Calculation of the concentration in the calcite determined thanks to carbonate dissolution experiment; ${ }^{\mathrm{d})}$ Measured by calcimetry.

XRD analyses revealed that, apart from some remaining calcite, limestone residues consisted of quartz, phyllosilicates (predominantly kaolinite, illite and interstratified for all samples, plus chlorite for S3), apatite (for S1, S4 and L), pyrite and sphalerite (for S3 and S4). Microprobe analyses provided evidences for the association of low concentrations of $\mathrm{Zn}$ and Fe together with $\mathrm{Si}$ and $\mathrm{Al}$, of low concentrations of $\mathrm{Zn}$ with $\mathrm{Ca}, \mathrm{P}$ and $\mathrm{F}$, and of high concentrations of $\mathrm{Fe}$ and $\mathrm{Zn}$ with $\mathrm{S}$. This was interpreted as the occurrence of $\mathrm{Zn}$ and Fe in phyllosilicates, of $\mathrm{Zn}$ in apatite and of small grains of mixed pyrite $\left(\mathrm{FeS}_{2}\right)$ and sphalerite $(\mathrm{ZnS})$.

Calcite was the main Mn-bearing phase. It suggests the occurrence of a solid solution with some rhodocrosite $\left(\mathrm{MnCO}_{3}\right.$; Lee et al., 2002). Calcite was a non-negligible Zn- and Fe-bearing phase, even if these elements were mainly bound to phyllosilicates and, to a lesser extend, to pyrite/sphalerite grains.

Soil-phosphate nodules were significant Zn-bearing phases as they represented $10 \%$ (in average) and $84 \%$ of the $>500 \mu \mathrm{m}$ fractions of the Bc- and BP-horizons, respectively (Figs. 1 and 2). Although soilphosphate nodules exhibited a slightly higher porosity than the limestone-phosphate nodules (S2P), 
both showed a very similar chemical and mineralogical composition (Table III, Fig. 3). Pedogenesis thus poorly influence phosphate nodules, which are mainly inherited. At the micrometer scale, the structure of phosphate nodules was highly heterogeneous. Zones with different grey levels were observed by SEM (Fig. 3). Microprobe and PIXE analyses gave low concentrations of Zn (several hundreds mg $\mathrm{kg}^{-1}$ ) in the zones of fluorapatite matrix (Fig. 3). On the opposite, much higher concentrations of $\mathrm{Zn}$ (several thousands $\mathrm{mg} \mathrm{kg}^{-1}$ ), as well as $\mathrm{Fe}$, were detected in the zones with very bright grey levels (Fig. 3). Goethite being the only Fe-bearing mineral identified on XRD spectra, these bright grey zones probably consist of goethite with high concentrations of $\mathrm{Zn}$ and are responsible for the high quantities of $\mathrm{Zn}$ in the phosphate nodules.

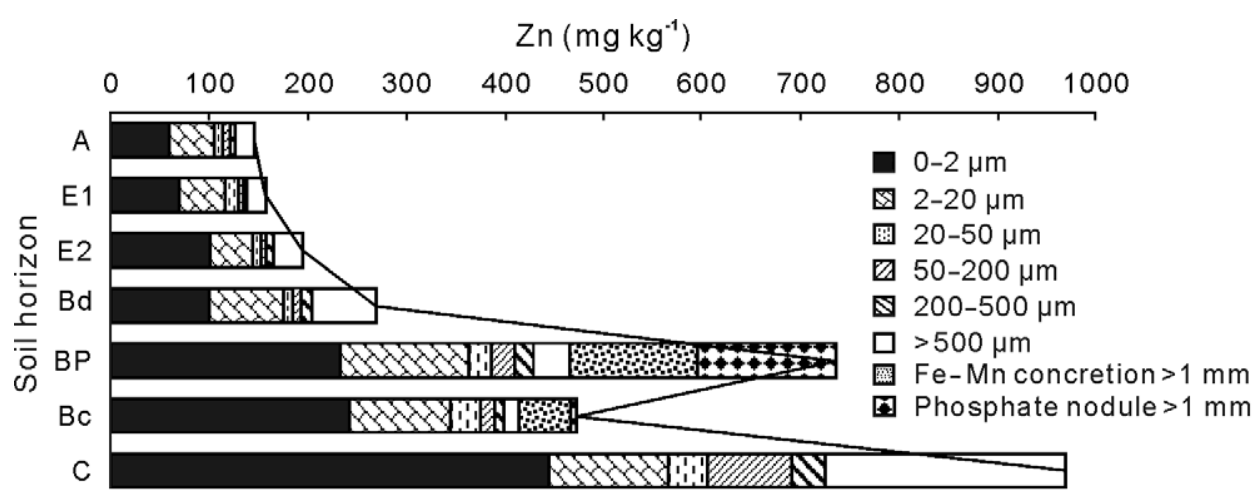

Fig. 1 Zinc particle-size distribution in the different soil horizons.

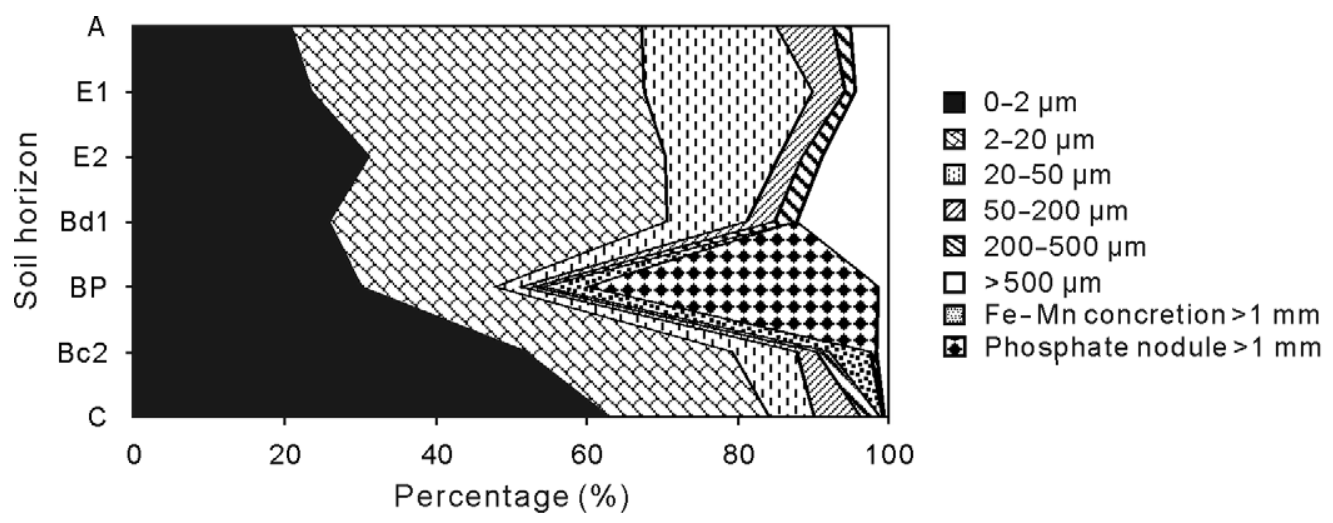

Fig. 2 Particle-size distribution in the solum.

Zinc redistribution along the solum during soil evolution

Zinc in the bulk soil samples increased with depth (Fig.1), notably in the C-horizon, with a peak in the BP-horizon due to the abundance of Zn-rich phosphate nodules (Figs. 2 and 3). In order to estimate the impact of pedological processes on $\mathrm{Zn}$ redistribution at the solum scale, the fluxes of $\mathrm{Zn}$ were quantified with mass balance calculations. Because redox processes mobilize Fe and Mn, whereas eluviation/illuviation processes mobilize $\mathrm{Si}$ and $\mathrm{Al}$, the fluxes of $\mathrm{Fe}, \mathrm{Mn}, \mathrm{Si}$ and $\mathrm{Al}$ were also quantified.

The volumetric strain ranged from $80 \%$ to $86 \%$ according to the horizon considered (Table II). These values were consistent with the amounts of $\mathrm{CaCO}_{3}$ in the limestones compared to those remaining in the soil horizons (Tables II and III), which indicates realistic results of mass balance calculations.

Since similar trends were observed for $\mathrm{Si}$ and $\mathrm{Al}$ on the one hand, and for Fe and $\mathrm{Mn}$ on the other hand, only results concerning $\mathrm{Al}, \mathrm{Fe}$ and $\mathrm{Zn}$ are shown in Fig. 4. These results indicate that important fluxes of $\mathrm{Al}(\mathrm{Si}), \mathrm{Fe}(\mathrm{Mn})$ and $\mathrm{Zn}$ occurred during pedogenesis, compared to their initial stocks in the respective parent limestones (Fig. 4). About one third of the initial $\mathrm{Al}$ ( $\mathrm{Si}$ ) stock was lost during the formation of the A- and E-horizons. These fluxes were roughly equal to those entering the underlying 


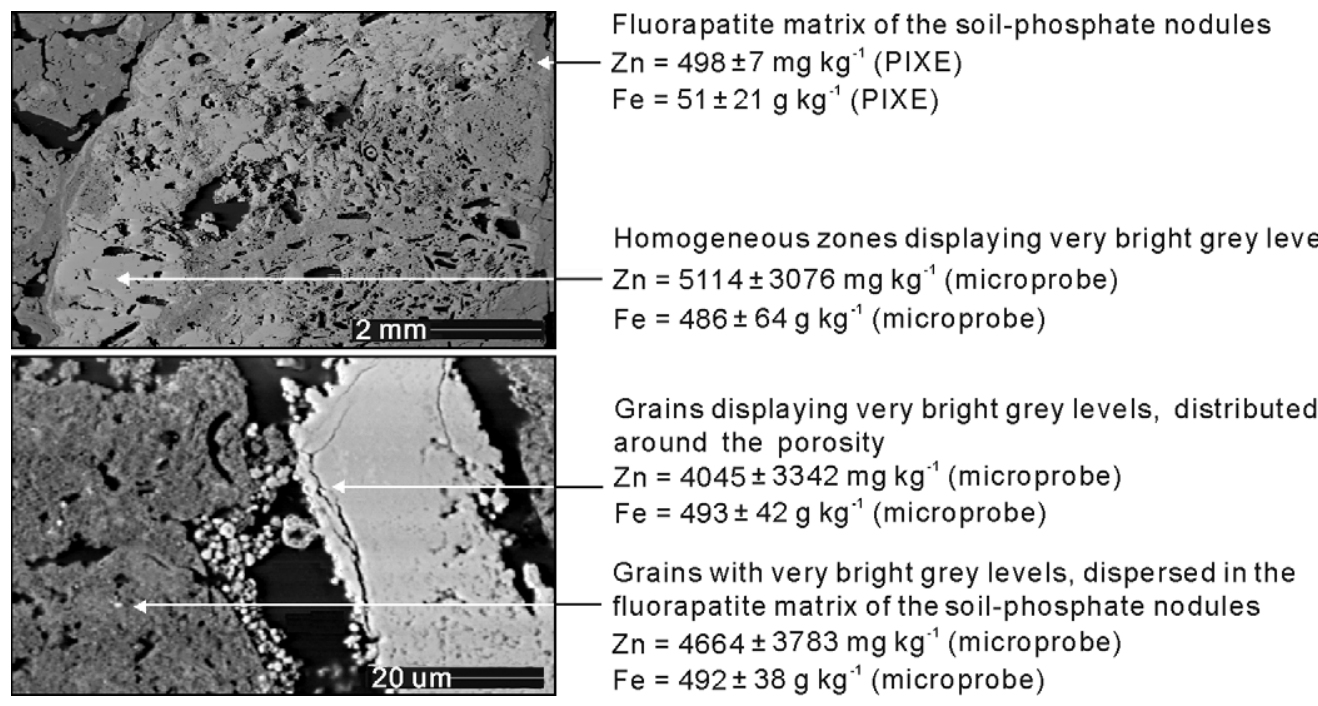

Fig. 3 Scanning electron microscope pictures (in the backscattered electron mode) of the phosphate nodules of the BP-horizon and associated average concentrations of zinc and iron, analyzed by microprobe and proton induced X-ray emission (PIXE), of the fluorapatite matrix and the zones with very bright grey level. Average concentration of zinc in the phosphate nodules of the BP-horizon is $928.6 \mathrm{mg} \mathrm{kg}^{-1}$.
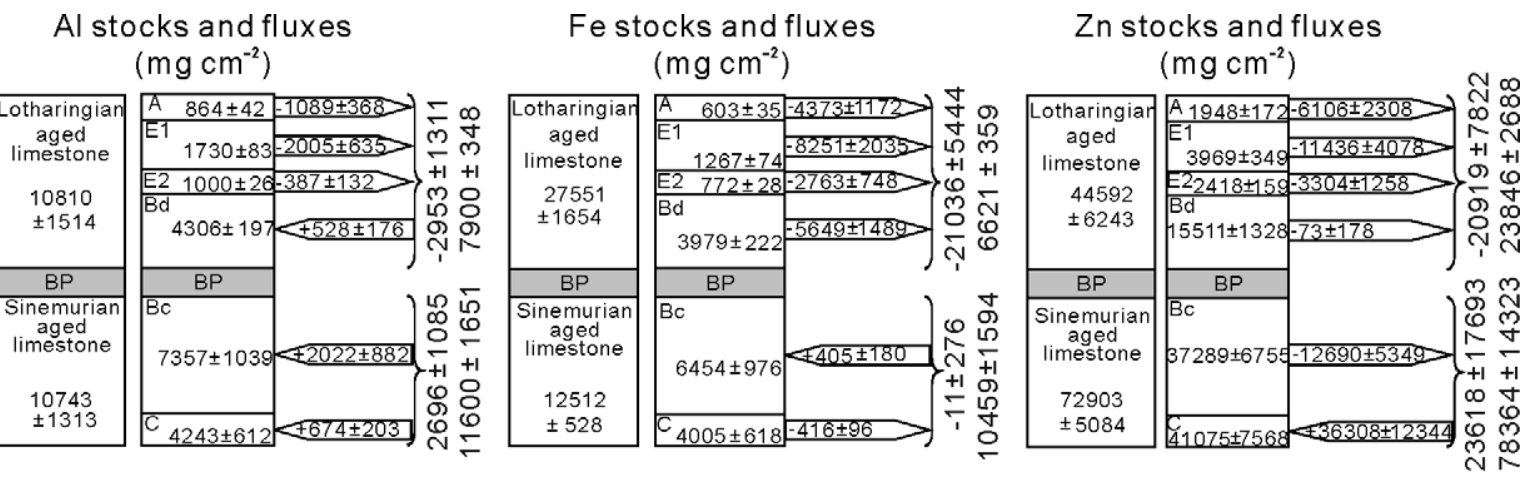

Fig. $4 \mathrm{Al}$, Fe and $\mathrm{Zn}$ stocks and fluxes in and from the different soil horizons, estimated by mass balance calculations following the method of Brimhall et al. (1991) modified by Egli and Fitze (2000) using Zr as invariant.

horizons (Fig. 4). About three quarters of the initial Fe (Mn) stock were lost during the formation of the A- to Bd-horizons. The formation of both the Bc- and C-horizons did not induce any net fluxes. It thus seems that the losses of $\mathrm{Fe}(\mathrm{Mn})$ recorded in the $\mathrm{A}$ - to Bd-horizons correspond to exportations out of the solum, while a redistribution occurred in the $\mathrm{Bc}$ - and C-horizons since the positive flux in the Bc-horizon balances the negative one in the C-horizon (Fig. 4). Except for the Bd-horizon, all fluxes of $\mathrm{Zn}$ were significant according to uncertainties calculated. About the half of the initial stock of $\mathrm{Zn}$ was lost during the formation of the A- to Bd-horizons. Zinc fluxes leaving the A- to Bc-horizons were roughly equal to the high one entering the C-horizon (Fig. 4).

Finally, the A- and E-horizons were systematically depleted in all elements. At the solum scale, Fe (Mn) was lost, while $\mathrm{Zn}$ and $\mathrm{Al}(\mathrm{Si})$ were not (Fig.4). Mass balance calculations do not explain the high concentration and input of $\mathrm{Zn}$ in the C-horizon. It may for instance be due to an important heterogeneity in the composition of the parent limestone or to lateral gains through the water table.

Impact of different pedological processes on the redistribution of zinc

Validation of solid phases extracted by each extraction step and location of Zn. Quantities of Fe, 
$\mathrm{Mn}$ and $\mathrm{Zn}$ extracted at each extraction step of the procedure are shown in Fig. 5. Recovery rates ranged from $87 \%$ to $94 \%$ for $\mathrm{Fe}, 79 \%$ to $98 \%$ for $\mathrm{Mn}$ and $93 \%$ to $112 \%$ for $\mathrm{Zn}$, which were acceptable for sequential extractions (Quevauviller, 1998).

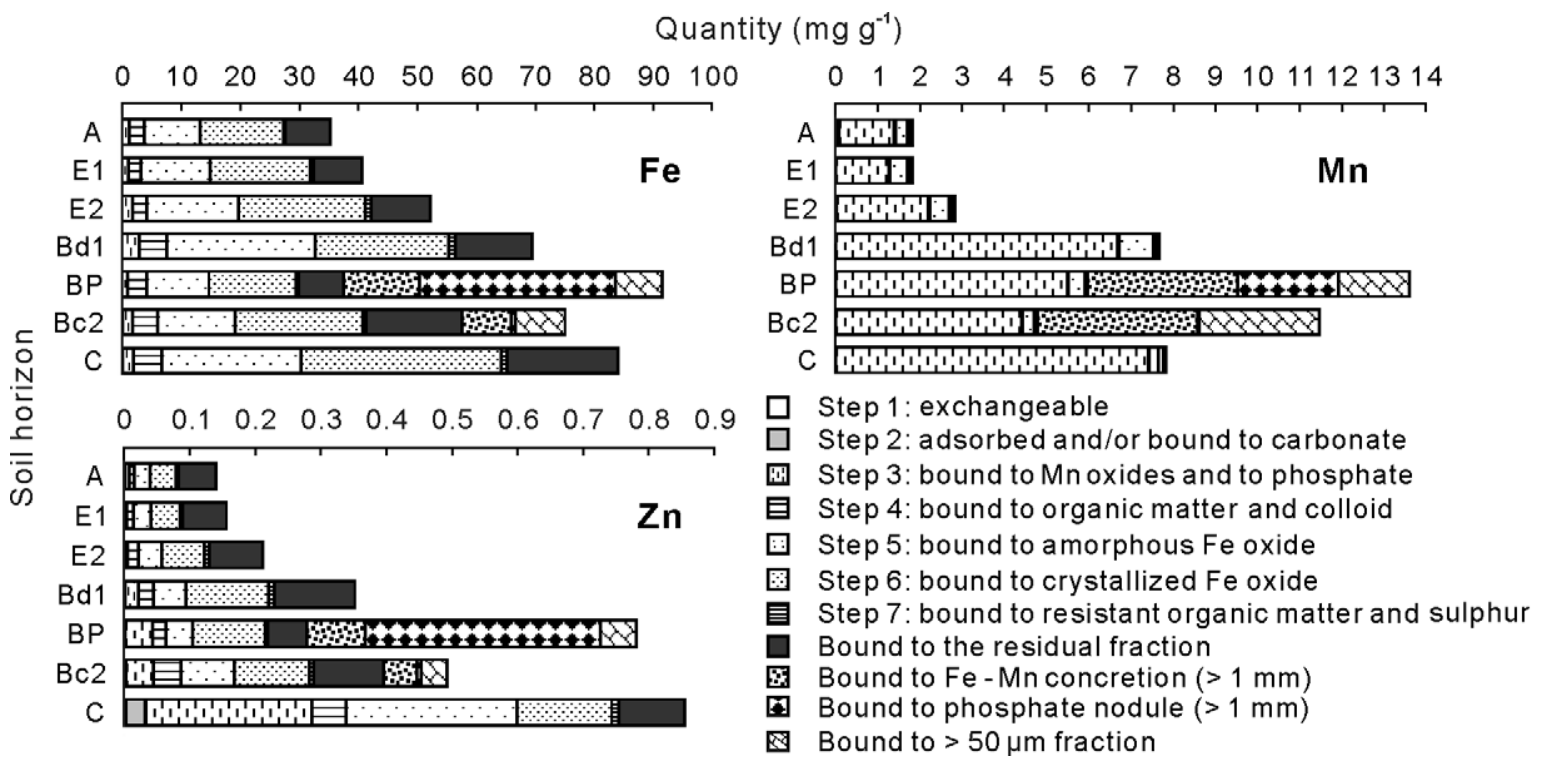

Fig. 5 Quantities of Fe, Mn and Zn extracted by sequential extractions along the solum. Sequential extractions were carried out on the $<50 \mu \mathrm{m}$ fractions for the BP- and Bc2-horizons and on the bulk samples for the other soil horizons.

Although extractions are not fully selective of a specific mineral phase, results remain informative when discussed with respect to the main solid phase(s) extracted during each step of the chosen procedure. Step 1 enables the extraction of the exchangeable Zn (Gupta and Aten, 1993), whereas step 2 enables the extraction of Zn sorbed and/or bound to carbonates (Han and Banin, 1995). These two first steps released almost negligible quantities of $\mathrm{Zn}$, except in the C-horizon where about $10 \mathrm{mg} \mathrm{kg}^{-1}$ of $\mathrm{Zn}$ were extracted during step 2 (Fig. 5).

Step 3 enables the extraction of Mn oxides (Hall et al., 1996), but also apatite (Land et al., 1999). The major part of Mn (68\% to $94 \%$ ), and only a few percentage of total Fe, were extracted during this step along the studied solum (Fig. 5). This step also released less than $10 \%$ of total Zn from the A- to Bc2-horizons and up to $30 \% \mathrm{Zn}$ to the C-horizon (Fig. 5). In addition, microprobe and PIXE analyses of the phosphate nodules of the BP-horizon detected only small quantities of $\mathrm{Zn}$ in the fluorapatite matrix (Fig. 3). The contribution of apatite to the quantities of $\mathrm{Zn}$ extracted during step 3 is therefore limited, although not totally excluded, and Zn extracted during step 3 was thus mainly released by Mn oxides. According to Manceau et al. (1997) who studied the Fe-Mn concretions of these soils, Mn oxides occur as birnessite that sorbs Zn, as also shown in polluted soils (Isaure et al., 2005).

Step 4 enables the extraction of Zn bound to OM (Benitez and Dubois, 1999), although sodium pyrophosphate also acts as a dispersive agent on small hydrated Fe oxide colloids (Jeanroy et al., 1984). Iron quantities extracted during step 4 were small, but non-negligible (Fig. 5). Considering the OM contents of the studied solum (Table II) and a mean concentration of Fe in plants of $300 \mathrm{mg} \mathrm{kg} \mathrm{kg}^{-1}$ (Angelone and Bini, 1992), the maximum quantity of Fe bound to OM should be $20 \mathrm{mg} \mathrm{kg}^{-1}$ soil. Since at least 2 g Fe $\mathrm{kg}^{-1}$ soil were extracted during step 4 (Fig. 5), it mainly corresponded to colloidal losses and not to extraction of OM. This assumption is heightened by the increase with depth of Fe extracted during step 4 (Fig. 5), while the OM contents decreased (Table II). This evolution with depth is not consistent with a complexation of Fe with OM, all the more that Fe has a weak affinity for soil OM (Burt et al., 2003). Therefore, the small Zn extracted during step 4 (Fig. 5) were also probably related to dispersion of Zn-bearing Fe colloids rather than to oxidative destruction of OM. 
Steps 5 and 6 enable the extraction of amorphous and crystalline Fe oxides, respectively (Hall et al., 1996). The high quantities of Fe (61\% to $71 \%)$ extracted during these steps suggest that this element mainly occurred as Fe oxides in the studied solum (Fig. 5). This was confirmed by the differential XRD spectra, which showed peaks of small intensities attributed to goethite and a very broad peak stretching from 0.21 to $0.38 \mathrm{~nm}$ attributed to ferrihydrite (Schulze, 1981). The quantities of Zn extracted during steps 5 and 6 ranged from $45 \%$ to $70 \%$ of total $\mathrm{Zn}$ depending on the depth, which suggests a significant association of Zn with amorphous and crystalline Fe oxides (Fig. 5). Such a strong affinity of Zn for Fe oxides was already observed in polluted soils (Manceau et al., 2000; Isaure et al., 2005).

Step 7 enables the extraction of Zn bound to resistant OM and sulphides (Hall et al., 1996). Quantities of Fe, Mn and Zn extracted during step 7 were low (Fig. 5). It confirms the lower affinity of $\mathrm{Zn}$ for OM than for Fe oxides, already shown in polluted soils (Burt et al., 2003).

Finally, the residual fraction consisted of quartz and of phyllosilicates according to XRD spectra. The significant residual quantities of $\mathrm{Fe}(19 \%$ to $28 \%$ of total $\mathrm{Fe})$ and $\mathrm{Zn}$ (12\% to $43 \%$ of total $\mathrm{Zn})$ were thus bound to phyllosilicates (Fig. 5). These latter minerals are important Fe- and Zn-bearing minerals in this solum, either through inclusion within their lattice or sorption at their surface and/or in their interlayer region (Manceau et al., 2000).

Sequential extractions finally showed that $\mathrm{Zn}$ is located in two main phases in the studied old solum: Fe and Mn oxides for the largest part and phyllosilicates. This $\mathrm{Zn}$ location results from successive pedological processes: carbonate dissolution, two stages of alternation of redox conditions, evolution of phyllosilicates, and eluviation/illuviation, as evidenced by Baize and Chrétien (1994). These pedological processes are responsible for the differentiation of the solum into horizons that are representative of a given pedological process: C-horizon for carbonate dissolution, Bc-horizon for primary redox processes, Bd-horizon for secondary redox conditions, and E- and A-horizons for eluviation, the BP-horizon being mainly inherited. In the following paragraphs, the fate of $\mathrm{Zn}$ during pedogenesis or how the different pedological processes act on the redistribution of $\mathrm{Zn}$ in the involved horizons is discussed.

Redistribution of $Z n$ by carbonate dissolution. The first process involved in the soil formation is the carbonate dissolution of the calcite matrix of the parent limestones. Despite its low concentrations in $\mathrm{Zn}, \mathrm{Fe}$ and $\mathrm{Mn}$, the large volume of calcite dissolved during the process implies high releases of $\mathrm{Zn}, \mathrm{Fe}$ and Mn into soil solution (Tables II and III). Carbonate dissolution still occurs in the C-horizon, as it is incomplete (Table II). Results suggest that, once released into soil solution, Fe and Mn subsequently precipitated as birnessite, ferrihydrite and goethite in the C-horizon (Fig. 5). The high amounts of Zn in $\mathrm{Mn}$ oxides and amorphous Fe oxides of the C-horizon indicate that, once precipitated, these newly formed phases bound a significant fraction of the dissolved Zn (Fig. 5). This assumption is supported by the strong enrichment of $\mathrm{Zn}$ into birnessite and ferrihydrite in the C-horizon (Table IV), which is favoured by its high pH value due to the persistence of carbonates (Table II) (Uygur and Rimmer, 2000). Once released into soil solution, geogenic $\mathrm{Zn}$ is thus trapped in the same solid phases like anthropogenic Zn in some polluted calcareous or pseudogley soils (Isaure et al., 2005).

TABLE IV

Extraction ratios of Fe in step 6 versus step 5 and of $\mathrm{Zn} / \mathrm{Mn}$ for step 3 and Zn/Fe for steps 5 and 6

\begin{tabular}{llcccc}
\hline Horizon & Step 6/step 5 (Fe) & Zn/Mn (step 3) & & Zn/Fe (step 5) & Zn/Fe (step 6) \\
\cline { 2 - 3 } \cline { 5 - 6 } A & 1.47 & 3.9 & 2.6 & 2.8 \\
E1 & 1.44 & 2.6 & 2.2 & 2.7 \\
E2 & 1.39 & 2.2 & 2.3 & 3.1 \\
Bd1 & 0.90 & 3.0 & 2.0 & 5.5 \\
BP & 1.39 & 7.7 & 3.8 & 7.5 \\
Bc2 & 1.64 & 9.7 & 6.3 & 5.3 \\
C & 1.44 & 34.2 & 11.0 & 4.3 \\
\hline
\end{tabular}


is a past succession of redox cycles supposed to have formed the Fe-Mn concretions in the Bc- and BP-horizons (Baize and Chrétien, 1994). Indeed, the $>500 \mu \mathrm{m}$ fractions of the Bc2- and BP-horizons contain $70 \%$ and $13 \%$ of Fe-Mn concretions, respectively (Fig. 2). The Fe-Mn concretions consist of goethite, birnessite (Manceau et al., 1997) and traces of ferrihydrite. They hold significant quantities of $\mathrm{Zn}$ (Figs. 1 and 5). Since the parent limestones are free of ferruginous oolites, Fe-Mn concretions are not inherited and have thus a pedological origin. The C-horizon, because of more permanent reductive conditions, displays only rare Fe-Mn concretions (Fig. 2). Once the pedological process established, its impact on $\mathrm{Zn}$ and Zn-bearing solid phases is examined. Thus the origin of Fe, Mn and Zn inside the concretions, the incorporation of $\mathrm{Zn}$ during their formation, and their evolution through time and related consequences on $\mathrm{Zn}$ fate are successively discussed.

Reductive cycles that occurred in the BP- and Bc-horizons induced the releases of Fe and Mn, due to the dissolution either of Fe oxides dispersed within the soil matrix or of pyrite-sphalerite $\left(\mathrm{FeS}_{2}-\mathrm{ZnS}\right)$ grains observed in the Sinemurian-aged limestone. The C-horizon also underwent redox conditions and is thus probably another source of Fe and Mn into soil solution.

Once in soil solution, $\mathrm{Mn}, \mathrm{Fe}$ and $\mathrm{Zn}$ are transferred from centimetric to decimetric scale and concentrate as concretions (Zhang and Karathanasis, 1997). This transfer occurred from the C- to the Bc-horizons during temporary elevations of the water table, as suggested by the Fe and Mn fluxes exiting the C-horizon equal to those entering the Bc-Horizon (Fig. 4). This assumption is supported by the concentric organization of Fe-Mn concretions in alternating rings of Mn or Fe oxides (Latrille et al., 2001). The formation of Fe-Mn concretions was also favored by the saturation of the adsorbing complex by $\mathrm{Ca}^{2+}$ in the Bc-horizon (Table II), which prevented the sorption of Fe ions and thus facilitated the individualization of Fe compounds (Bottner, 1972). From the C- to the Bc-horizons, the quantities of Mn extracted by step 3 decreased (Fig. 5). This result is consistent with a concentration of birnessite in the Fe-Mn concretions at the expense of the birnessite dispersed in the matrix. The Fe-Mn concretions display an association of Zn-enriched areas with Mn-enriched ones (Manceau et al., 1997; Latrille et al., 2001), surely due to the strong affinity of Zn for the surface of birnessite (Lanson et al., 2002). In addition, the significant decrease from the $\mathrm{C}$ - to the BP-horizons of the $\mathrm{Zn} / \mathrm{Mn}$ ratio in step 3 (Table IV) and the flux of Zn exiting the Bc-horizon (Fig. 4), possibly reflect a loss of Zn during the dissolution of the dispersed birnessite and the subsequent reconcentration of $\mathrm{Mn}$ in the Fe-Mn concretions.

Once formed, the Fe-Mn concretions undergo aging process. Indeed, the goethite/ferrihydrite ratio (indicated by the Fe ratio of step 6/step 5) increased from the C- to the Bc2-horizons (Table IV). The decrease of the $\mathrm{Zn} / \mathrm{Fe}$ ratio in step 5 from the $\mathrm{C}$ - to the BP-horizons, concomitant with the increase of the same ratio in step 6 (Table IV), is consistent with a release of Zn during the process of transformation of the ferrihydrite into goethite (Kaur et al., 2006). Despite the oldness of this solum, this transformation is still incomplete, probably because high concentrations of elements such as Zn or Mn slow down the kinetics of this reaction (Cornell and Giovanoli, 1987).

We thus show that if $\mathrm{Fe}$ and $\mathrm{Mn}$ oxides are the main phases scavenging $\mathrm{Zn}$ from soil solution, as already found in some polluted soils (Manceau et al., 2000; Isaure et al., 2005), the subsequent aging of these oxides induces $\mathrm{Zn}$ losses in the environment.

Redistribution of $Z n$ by secondary redox processes. The third process involved in soil formation is a second stage of redox conditions. They result from the occurrence of the very compact BP-horizon, which hinders water percolation (by field observations), hence the formation of a temporary perched water table in the Bd-horizon and preferential lateral water flow. This temporary water table leads to the reductive dissolution of oxide cements, macroscopically proven by the bleached zones in the Bd-horizon, and to the weathering of Fe-Mn concretions. Moreover, the desaturation of the adsorbing complex induces a decrease in $\mathrm{pH}$ (Table II) that favors the destruction of oxide cements. From the BPto the E-horizons, Fe losses occurred (Fig. 4), due to a net decrease in Fe-Mn concretions resulting from their weathering. From the Bd- to the E-horizons, the quantities of Fe and Mn bound to ferrihydrite, goethite and birnessite decreased (Fig. 5). The quantities of Mn occurring as birnessite was divided by three from the Bd1- to the E2-horizons, those of Fe as ferrihydrite by two, while those of Fe as 
goethite decreased only from the E2- to E1-horizons (Fig. 5). Thus, Mn was lost in a greater proportion and before $\mathrm{Fe}$, in agreement with the relative sensibility of the different oxides to redox conditions. In addition, the quantities of $\mathrm{Zn}$ bound to these oxides decreased similarly from the Bd- to the E-horizons (Fig. 5), while exported fluxes of Zn increased (Fig.4). Since the BP-horizon induced a preferential lateral water flow and according to mass balance calculations (Fig. 4), Fe, Mn and Zn released into soil solution by the current dissolution of Fe and Mn oxides were mainly exported laterally.

Redistribution of $Z n$ due to the evolution of phyllosilicates and eluviation/illuviation. Zinc was largely bound to the $0-2$ and 2-20 $\mu \mathrm{m}$ fractions (Fig. 1) and to the residues from sequential extractions (Fig. 5). Phyllosilicates are thus important Zn-bearing phases. The quantities of Zn bound to the 0-2 $\mu \mathrm{m}$ fraction decreased toward soil surface (Fig. 1), together with the 0-2 $\mu \mathrm{m}$ fraction (Fig. 2), which can be due to an evolution of the composition of the phyllosilicates and/or eluviation of the 0-2 $\mu \mathrm{m}$ fraction.

Illite, vermiculite, smectite, chlorite, interstratified phyllosilicates, and mainly kaolinite occurred in

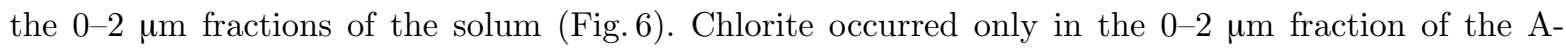
and E-horizons as shown by the peak at $1.41 \mathrm{~nm}$ (Fig. 6), which probably results from the physical breakdown of chlorite in the 2-20 $\mu \mathrm{m}$ fractions of the A- and E-horizons (Hardy et al., 1999). The relative proportion of phyllosilicates of the 0-2 $\mu \mathrm{m}$ fraction evolved with depth (Fig. 6), whatever the parent limestones of the soil horizon considered. However, the mineralogical evolution of phyllosilicates is apparently restricted to a small proportion, thus can not significantly affect the redistribution of $\mathrm{Zn}$.

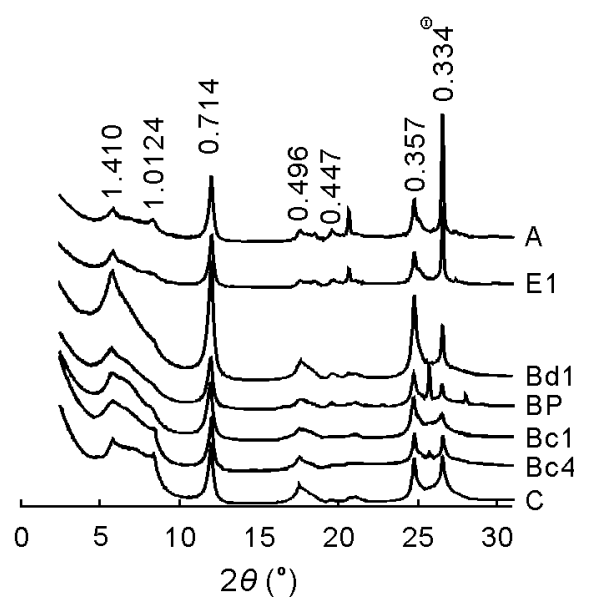

Fig. 6 X-ray diffraction spectra of the natural oriented slides of the $0-2 \mu \mathrm{m}$ fractions for the different soil horizons. Intensities of (001) quartz peaks $\left({ }^{\Theta}\right)$ are normalized to that of the A-horizon. Interreticular distances (in nm) are reported for main peaks.

Oxide cements were not dissolved before particle-size analyses, but Baize and Chrétien (1994) showed that the decrease in the quantities of the 0-2 $\mu \mathrm{m}$ fraction toward soil surface is maintained after acidic dissolution of oxide cements. It proves that this evolution results from an eluviation of $0-2 \mu \mathrm{m}$ fractions from the A- to E-horizons and not from its cementation into 2-20 $\mu \mathrm{m}$ fractions. Indeed, the sufficient desaturation of the adsorbing complex in the A- and E-horizons facilitates the transfer of fine particlesize constituents (Table II) (Bottner, 1972). Besides, significant Al (Si) losses occurred in the A- and E-horizons (Fig. 4). Moreover, from the Bd1- to the A-horizons, the peak intensity ratio of phyllosilicates to quartz decreased in bulk samples and 0-2 $\mu \mathrm{m}$ fractions (from 2.1 to 0.5; Fig. 6), concomitant with an increase of $\mathrm{Si} / \mathrm{Al}$ ratio in the residual fraction from extractions (from 3.6 to 6.5). Losses of $\mathrm{Al}$ and $\mathrm{Si}$ actually arise from the eluviation of phyllosilicates from the A- and E-horizons, while quartz is relatively enriched. Consequently, the decrease in the quantities of $\mathrm{Zn}$ bound to $0-2 \mu \mathrm{m}$ fractions surely results from the eluviation of 0-2 $\mu \mathrm{m}$ fractions from the A- and E-horizons. This also explains the decreases in Zn quantities and concentrations bound to phyllosilicates from the Bd- to the A-horizon (Fig. 5). Except quartz, all mineral phases of the 0-2 $\mu \mathrm{m}$ (Fig.6) and 2-20 $\mu \mathrm{m}$ fractions, i.e., phyllosilicates, 
Fe oxides (goethite and ferrihydrite) and apatite, likely contain significant amounts of Zn. Therefore, eluviation, together with secondary redox processes that dissolve oxide cements as previously mentioned, is responsible for the losses of $\mathrm{Fe}, \mathrm{Mn}$ and $\mathrm{Zn}$ observed in the A- and E-horizons (Fig. 4).

At last, the eluviated phyllosilicates can either be accumulated within the solum or lost. Mass balance calculations showed only small enrichments of $\mathrm{Al}$ and $\mathrm{Si}$ in the Bd-horizon relative to losses recorded from the overlying A- and E-horizons (Fig.4). Besides, the thin argilans in the Bd-horizons observed by petrography exhibit a restricted illuviation. Since the compact underlying BP-horizon induces a preferential lateral water flow, the eluviated phyllosilicates are mainly transferred laterally outside of the solum. Since phyllosilicates are important Zn-bearing minerals (Fig. 5), the illuviation in the Bd-horizon, even if restricted, may nevertheless balance losses of $\mathrm{Zn}$ induced by the ongoing secondary redox process leading to significant losses of Fe and Mn (Fig. 4). This could explain the lack of $\mathrm{Zn}$ flux from or into the Bd-horizon.

\section{CONCLUSIONS}

Four pedological processes (i.e., carbonate dissolution, two stages of redox processes and eluviation) contributed to the redistribution of $\mathrm{Zn}$, which occur in three main pools in the parent limestones according to their fate: the easily and highly mobilized pool of $\mathrm{Zn}$ released into soil solution, i.e., dispersed in calcite, mobilized as soon as carbonate dissolution begins, and bound to pyrite-sphalerite grains, mobilized when redox conditions become enough oxidative; the pool of Zn with a lower and rather physical mobility, i.e., bound to potentially eluviated phyllosilicates; and the non-mobilized pool of $\mathrm{Zn}$, i.e., bound to goethite phases in the inherited phosphate nodules. Due to residual enrichment, Zn concentrations in the soil were higher than those in parent limestones. Birnessite, ferrihydrite and goethite dispersed in soil horizon trapped high quantities of Zn during their formation, but non-negligible quantities exited the solum through a bottom water table. Afterwards, primary redox conditions induced the release of $\mathrm{Zn}$ and Fe into soil solution, then individualization of Fe and Mn into Zn-rich concretions. Both processes and subsequent aging of the concretions formed induced significant exportation of $\mathrm{Zn}$ through the bottom water table. Thus even if oxides are the main phases scavenging $\mathrm{Zn}$ from the soil solution, the subsequent evolution and aging of these oxides induce $\mathrm{Zn}$ losses in the environment. Secondary redox conditions, as well as ongoing desaturation, promoted the weathering of Fe and $\mathrm{Mn}$ oxides in cements and concretions. This process caused other losses of $\mathrm{Zn}$ through lateral exportation in an upper water table. Concomitantly, lateral eluviation occurred at the top of the solum. Eluviation was also responsible for $\mathrm{Zn}$ loss, but this $\mathrm{Zn}$ bound to phyllosilicates is not bioavailable.

Combined approaches including mass balance allow better quantification of the impact of different pedological processes on the long-term fate of $\mathrm{Zn}$ in soils. However, further work is required to assess the role of each pedological process on $\mathrm{Zn}$ redistribution. A mass balance calculation of $\mathrm{Zn}$ related to each process may eventually fill in this gap. Moreover, the kinetic of the release of Zn over a long time is crucial, since environmental hazards depend on how slow or fast the release is.

\section{REFERENCES}

Angelone, M. and Bini, C. 1992. Trace elements concentrations in soils and plants of Western Europe. In Adriano, D. C. (ed.) Biogeochemistry of Trace Elements. Lewis Publisher, Boca Raton, London. pp. 19-60.

Baize, D. and Chrétien, J. 1994. Soil mantles of the Sinemurian structural surface in Burgundy. Morphological and pedo-geochemical characteristics. Etudes et Gestion des sols (in French). 2: 7-27.

Benitez, L. N. and Dubois, J. P. 1999. Evaluation of the selectivity of sequential extraction procedures applied to the speciation of cadmium in soils of the Swiss Jura. Int. J. Environ. An. Ch. 74: 289-303.

Bottner, P. 1972. The Pedogenesis on Parent Limestones in a Mediterranean-Alpine Bioclimatic Sequence in the South France (in French). Ph.D. Dissertation. Faculté des Sciences de Montpellier. 271pp.

Brimhall, G. H., Lewis, C. J., Ford, C., Bratt, J., Taylor, G. and Warin, O. 1991. Quantitative geochemical approach to pedogenesis: Importance of parent material reduction, volumetric expansion, and eolian influx into lateritization. Geoderma. 51: 51-91.

Burt, R., Wilson, M. A., Keck, T. J., Dougherty, B. D., Strom, D. E. and Lindahl, J. A. 2003. Trace element speciation 
in selected smelter-contaminated soils in Anaconda and Deer Lodge Valley, Montana, USA. Adv. Environ. Res. 8: $51-67$.

Cornell, R. M. and Giovanoli, R. 1987. Effect of manganese on the transformation of ferrihydrite into goethite and jacobsite in alkaline media. Clay. Clay Miner. 35: 11-20.

Cornu, S., Salvador-Blanes, S., Hardy, M., Clozel, B., Crouzet, C., Proix, N. and Guerin, A. 2006. Location of trace elements in unpolluted soils by a combined method. Commun. Soil Sci. Plan. 37: 1077-1 101.

Egli, M. and Fitze, P. 2000. Formulation of pedologic mass balance based on immobile elements: A revision. Soil Sci. 165: $437-443$.

Gupta, S. K. and Aten, C. 1993. Comparison and evaluation of extraction media and their suitability in a simple model to predict the biological relevance of heavy metal concentrations in contaminated soils. Int. J. Environ. An. Ch. 51: $25-46$.

Hall, G. E. M., Vaive, J. E., Beer, R. and Hoashi, M. 1996. Selective leaches revisited with emphasis on the amorphous Fe oxyhydroxides phase extraction. J. Geochem. Explor. 56: 59-78.

Han, F. X. and Banin, A. 1995. Selective sequential dissolution techniques for trace metals in arid-zone soils: The carbonate dissolution step. Commun. Soil Sci. Plant. 26: 553-576.

Hardy, M., Jamagne, M., Elsass, F., Robert, M. and Chesneau, D. 1999. Mineralogical development of the silt fractions of a Podzoluvisol on loess in the Paris Basin (France). Eur. J. Soil Sci. 50: 443-456.

Hita, P. and Torrent, J. 2005. Weathering of pyrite and sphalerite in soils contaminated with pyritic sludge. Soil Sci. Soc. Am. J. 69: 1314-1319.

Isaure, M. P., Manceau, A., Geoffroy, N., Laboudigue, A., Tamura, N. and Marcus, M. A. 2005. Zinc mobility and speciation in soil covered by contaminated dredged sediment using micrometer-scale and bulk-averaging X-ray fluorescence, absorption and diffraction techniques. Geochim. Cosmochim. Ac. 69: 1173-1198.

Jeanroy, E., Guillet, B. and Ortiz, R. 1984. Pedogenetic uses of the study of iron forms by extraction reagents: Study case of brown and podzolized soils on crystalline rocks. Sci. du sol (in French). 3: 199-211.

Kabata-Pendias, A. and Pendias, H. 2001. Trace Elements in Soils and Plants. C.R.C. Press, Boca Raton, FL.

Kaur, N., Singh, B., Gräfe, M. and Kennedy, B. J. 2006. Structural incorporation of trace metals in goethite $(\alpha-\mathrm{FeOOH})$ in di-metal systems. In Proceeding of the 18th World Congress of Soil Science. "Frontiers of Soil Science: Technology and the Information Age". July 9-15, 2006. Philadelphie, Pennsylvania, USA.

Land, M., Ohlander, B., Ingri, J. and Thunberg, J. 1999. Solid speciation and fractionation of rare earth elements in a Spodosol profile from northern Sweden as revealed by sequential extraction. Chem. Geol. 160: 121-138.

Lanson, B., Drits, V. A., Gaillot, A. C., Silvester, E., Plançon, A. and Manceau, A. 2002. Structure of heavy-metal sorbed birnessite: Part 1. Results from X-ray diffraction. Am. Mineral. 87: 1631-1645.

Latrille, C., Elsass, F., van Oort, F. and Denaix, L. 2001. Physical speciation of trace metals in Fe-Mn concretions from a rendzic lithosol developed on Sinemurian limestones (France). Geoderma. 100: 127-146.

Lee, Y. L., Reeder, R. J., Wenskus, R. W. and Elzinga, E. J. 2002. Structural relaxation in the $\mathrm{MnCO}_{3}-\mathrm{CaCO}_{3} \mathrm{solid}$ solution: A Mn K-edge EXAFS study. Phys. Chem. Miner. 29: 585-594.

Manceau, A., Hargé, J. C., Bartoli, C., Silvester, E., Hazemann, J. L., Mench, M. and Baize, D. 1997. Sorption mechanism of zinc and lead on birnessite: Application to their speciation in contaminated soils. In Proceeding of the Fourth International Conference on the Biogeochemistry of Trace Elements. June 23-26, 1997. University of California, Berkeley, California, USA.

Manceau, A., Lanson, B., Schlegel, M. L., Hargé, J. C., Musso, M., Eybert-Berard, L., Hazemann, J. L., Chateigner, D. and Lamble, G. M. 2000. Quantitative Zn speciation in smelter-contaminated soils by EXAFS spectroscopy. Am. J. Sci. 300: 289-343.

Nicolini, P. 1990. Science of Mineral Concentrations in Stratiform Deposits and Mining Exploration (in French). Techniques et Documentation Lavoisier, Paris.

Quevauviller, P. 1998. Operationally defined extraction procedures for soil and sediment analysis. I. Standardization. Trend. Anal. Chem. 17: 289-298.

Salomons, W., Förstner, U. and Mader, P. 1995. Heavy Metals: Problems and Solutions. Springer-Verlag, Berlin.

Schulze, D. G. 1981. Identification of soil iron oxide minerals by differential X-ray diffraction. Soil Sci. Soc. Am. J. 45: $437-440$.

Uygur, V. and Rimmer, D. L. 2000. Reactions of zinc with iron-oxide coated calcite surfaces at alkaline pH. Eur. J. Soil Sci. 51: $511-516$.

Zhang, M. and Karathanasis, A. D. 1997. Characterization of iron-manganese concretions in Kentucky Alfisols with perched water tables. Clay. Clay Miner. 45: 428-439. 